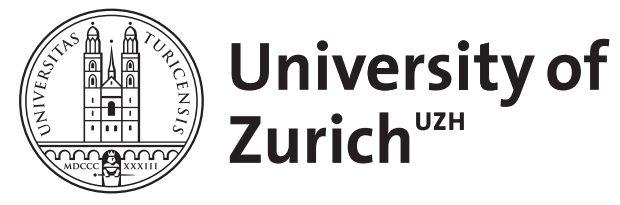

Hearsay and lexical evidentials in old germanic languages, with focus on old English

\author{
Timofeeva, Olga
}

Posted at the Zurich Open Repository and Archive, University of Zurich

ZORA URL: https://doi.org/10.5167/uzh-82413

Book Section

Published Version

Originally published at:

Timofeeva, Olga (2013). Hearsay and lexical evidentials in old germanic languages, with focus on old English. In: Diewald, Gabriele; Kahlas-Tarkka, Leena; Wischer, Ilse. Comparative Studies in Early Germanic Languages: With a Focus on Verbal Categories. Amsterdam: Benjamins, 169-194. 


\section{John Benjamins Publishing Company}

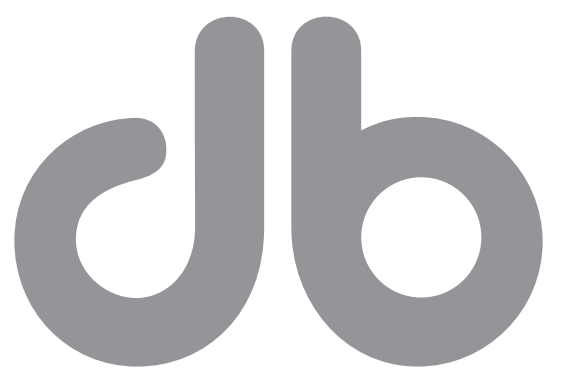

This is a contribution from Comparative Studies in Early Germanic Languages. With a focus on verbal categories.

Edited by Gabriele Diewald, Leena Kahlas-Tarkka and Ilse Wischer.

(c) 2013. John Benjamins Publishing Company

This electronic file may not be altered in any way.

The author(s) of this article is/are permitted to use this PDF file to generate printed copies to be used by way of offprints, for their personal use only.

Permission is granted by the publishers to post this file on a closed server which is accessible to members (students and staff) only of the author's/s' institute, it is not permitted to post this PDF on the open internet.

For any other use of this material prior written permission should be obtained from the publishers or through the Copyright Clearance Center (for USA: www.copyright.com). Please contact rights@benjamins.nl or consult our website: www.benjamins.com Tables of Contents, abstracts and guidelines are available at www.benjamins.com 


\title{
Hearsay and lexical evidentials in Old Germanic languages, with focus on Old English
}

\author{
Olga Timofeeva \\ University of Zurich, Switzerland
}

This article offers a paradigmatic survey of auditory evidential constructions in Old English: direct-perception constructions - accusativus cum infinitivo (ACI) introduced by the auditory (ge)hieran 'to hear' ( $($ ge $)$ hieran $+\mathrm{ACI})$ - and hearsay-evidence constructions, consisting of the verb (ge)hieran with the infinitive of a verb of utterance ( $\mathrm{ge}$ )hieran+Inf), followed by a compliment clause, a prepositional clause, or a parenthetical. Comparative data from other Old Germanic languages suggests a common origin of both constructions. It is further hypothesised that these two do not go back to the same Proto-Germanic construction: (ge)hieran+ACI is more likely to have arisen from the reanalysis of the verbal noun in I heard his speech into an ACI with a verb of 'speaking' I heard him speak, while (ge)hieran+Inf could have developed from I heard the story into I heard (the) say with the verb of 'saying'.

\section{Introduction}

It is a well-known fact that Germanic languages, and Western European languages more generally, do not encode evidentiality in the verbal morphology (Chafe 1986; Aikhenvald 2004:355; Whitt 2010:1-3; Wiemer 2010:62-67). What these languages do instead is signify information source by various lexical means: perception verbs (e.g. 'see, 'hear'), modal verbs (e.g. 'must'), verbs of utterance (e.g. 'speak,' 'say'), sentential adverbs (e.g. 'apparently', 'supposedly'), etc. (Diewald \& Smirnova 2010b: 1-6). ${ }^{1}$ Among these means, perception verbs and verbs with a 'say'-component are ones that occur most frequently cross-linguistically and often

1. For a survey of these lexical means in English and German, see Whitt (2010:14-39). A classification of hearsay lexemes in other European languages (defined geographically and including Turkish, Armenian, Georgian, and Estonian) is given in Wiemer (2010:69-113); see also other contributions to Diewald and Smirnova's 2010a volume.

(C) 2013. John Benjamins Publishing Company

All rights reserved 
grammaticalise into morphological evidentials (Aikhenvald 2004:271-274). It is the relation between these two groups (perception and utterance) that I investigate here and illustrate with data from the Old Germanic languages, which seldom come into typological discussions of evidentiality in literature. More specifically I address Old English auditory perception verb $(g e)$ hieran $^{2}$ 'hear' and its infinitival complements and compare these findings to cognates of ( $g$ e)hieran in other Old Germanic languages and their complementation patterns. I, thus, share a broader understanding of evidentiality and evidential markers, one that includes not only grammatical mark-up but also lexical means (see Diewald \& Smirnova (eds.) 2010a in general and Wiemer (2010:60) in particular), such as verbs of perception and verbs or verbal phrases denoting hearsay evidence. Following existing classifications, I distinguish between two basic groups of evidentials, with two subgroups within the second group:

1. Direct/first-hand perception

2. Indirect perception

a. Indirect/second-hand inference

b. Indirect/second-hand hearsay evidence (Chafe 1986:261-264; Willett 1988: 57; Aikhenvald 2004:25, 63-66; Plungian 2010:35-38).

I address these groups in more detail in the relevant sections of this article, illustrate them with Old English (OE) examples and supply comparative material from other Old Germanic languages if it is available. The aim of this comparison (presented in Sections 3.1 and 3.2) is to establish whether auditory evidential constructions in OE and other Old Germanic languages developed from a common stock, to analyse the specific construction types in which (ge)hieran and its cognates are used, and to find out what specific evidential meanings are bound to these constructions. These findings are summarised in Section 3.3. Further in 3.4, I attempt a more detailed analysis of the verbs of utterance that are used in evidential constructions in combination with (ge)hieran in Old English and address the co-lexicalisation of hear-say in English and German, which is to lay the ground for my discussion of the origin of the direct auditory perception and hearsay evidence constructions in Proto-Germanic in Section 3.5. The bulk of my data presented in Section 3 deals with hear+Inf constructions which would in present-day English correspond to something like I've heard say that he is a nice chap. These are typically treated in literature as accusativus cum infinitivo (ACI) constructions with ellipsis of the accusative (see Note 13 below). Thus, a full construction would be I've heard people say that he is a nice chap. In 3.5 I suggest that hear+Inf

2. I use the spelling (ge)hieran to refer collectively to both the prefixed verb gehieran and the simplex hieran.

(C) 2013. John Benjamins Publishing Company

All rights reserved 
and hear+ACI could have developed independently of each other at a stage when Proto-Germanic infinitives were still construed as verbal nouns. Corpus data for the study is introduced in Section 2.

\section{The data}

OE data for this study come from the Dictionary of Old English Web Corpus (DOEC), "an online database consisting of at least one copy of every surviving Old English text" (c. 700-1150) and containing about 3,033,000 words, and from the syntactically annotated York-Toronto-Helsinki Parsed Corpus of Old English Prose (YCOE). For comparative Old Germanic material, I consulted Heimskringla Project, an online database of some 2,000 Old Norse texts (primarily the Eddas, the Icelandic sagas and skaldic poetry); Project Wulfila, an online database of surviving Gothic texts (Gothic Bible and minor fragments), with syntactic annotation; and TITUS online database (Thesaurus Indogermanischer Text- und Sprachmaterialien) for Old High German and Old Saxon. The chief criterion for choosing these resources on the Old Germanic languages was their availability. In selecting Old Germanic examples for this study, I limit my upper time frame to the end of the OE period and only include those whose composition can be dated to before 1150 to be able to compare roughly contemporary developments. Later material is quoted on a few occasions when this criterion cannot be met. It is not my intention here to attempt a statistical evaluation of auditory and hearsay evidentials in Gothic, Old High German, Old Saxon, and Old Norse, but rather to suggest a typology of cognate constructions in these languages and to check whether they could have developed from a common stock. It is to be hoped that with the emergence of new electronic resources for these languages, the results of this study could be revisited and corroborated with a more extensive analysis of data going beyond Old English. To trace the long-term diachronic development of English auditory and hearsay evidentials, I also examined the Corpus of Middle English Prose and Verse (CME) and the Oxford English Dictionary (OED).

\section{OE (ge)hieran: Its complements and cognates}

To obtain OE data from the YCOE, I ran CorpusSearch Programme with several input commands, such as

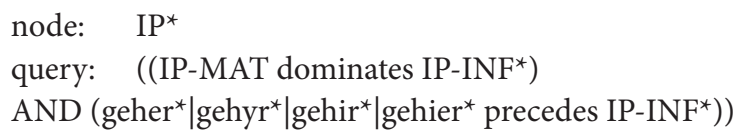

(C) 2013. John Benjamins Publishing Company

All rights reserved 
I also searched for simplex forms of hieran (with spelling variants) preceding the infinitival clause (IP-INF) and for the reversed order of constituents - infinitival clauses followed by (ge)hieran. I then supplemented these data with proximity searches in the DOEC for collocations of (ge)hieran with the infinitives that had been yielded by the YCOE, so as to obtain the data from verse texts and to make sure that I get the constructions which might have been missed by the parser. ${ }^{3}$ This procedure yielded a total of 166 hits. The complete list of verbs used as infinitival complements of ( $\mathrm{ge}$ )hieran is as follows:

- secgan 'to say' (106 tokens)

- roedan 'to read, explain' (23)

- sprecan 'to speak' (15)

- nemnan 'to name, call' (7)

- reccan 'to tell, explain' (7)

- cwepan 'to say' (2)

- cypan 'to tell' (2)

- mapelian 'to speak' (2)

- hrutan 'to snore' (1)

- huntan 'to hunt' $(1)^{4}$

Among these the source of information (the direct object of the perception verb) is implicit (henceforth (ge)hieran+Inf construction) in 144 tokens (or 87 per cent of the data), as below:

(1) Hwot, we nu gehyrdon secgan hwylc hit is on helle what we now hear-PRET-PL say-INF which it is in hell

to bionne

to be

(Homs 4 222)

'Lo, we have now heard say what it is like to be in hell'

In the remaining 22 tokens (13 per cent), we have a full accusativus cum infinitivo (ACI) construction (henceforth (ge)hieran+ACI construction):

(2) Of pore tide, pe ic arest mid pe on pisum westene eardode, of that time that I first with thee in this wasteland lived ic pe gehyrde sprecan on afenne and on

I thou-ACC hear-PRET-1sG speak-INF on evening and on

3. This double-checking proved to be useful in my previous studies: Timofeeva (2010) and Kilpiö \& Timofeeva (2011).

4. I examine the example with huntan in my dissertation (Timofeeva 2010) on p. 135. For the reasons explained there, I consider it very marginal for the present analysis.

(C) 2013. John Benjamins Publishing Company

All rights reserved 
arenmergen, ic nat mid hwoene (LS 10.1 (Guth) 20.73) early-morning I not-know with whom

'At the time when I first lived with you in the wilderness, I heard you speak in the evening and early morning I did not know with whom'

In what follows I survey these complementation patterns in more detail. Comparative material from other Germanic languages: Gothic, Old High German (OHG), Old Saxon (OS), and Old Norse (ON) is provided (if available) for each OE pattern.

\subsection{Direct perception}

Auditory evidentials are part of a bigger subsystem of sensory or non-visual perception. They introduce information acquired through hearing and signal direct access to this information (Chafe 1986:267; Willett 1988:57; Plungian 2010:37). Thus hearing and the event that is heard are construed as happening simultaneously. Compare examples from present-day English and German: I hear Karen singing; Ich höre Karen singen (Whitt 2010:9).

\subsection{1 (ge)hieran+ACI construction}

Syntactically this evidential value can be coded by full ACI constructions in OE (similarly to modern and present-day English (Whitt 2010:140-145)). Infinitival complements in these constructions are typically verbs of sound emission (Timofeeva 2010:135), as below:

(3) Đa he poene cyrcward gehyrde ofer eall when he that-ACC churchwarden-ACC hear-PRET-3sG over all hrutan, pa ne woende he him nanes incymes (Leof 31.34) snore-INF then not thought he him no entrance

'when he heard the churchwarden snore very loudly, he thought that it would not be possible for him to enter [the church]'

More specifically and overwhelmingly so - 20 out of 22 occurrences - the complements are verbs of utterance (see Table 1):

(4) Hwot ða cempan ða hine gelohton. for pan ðe what the soldiers then him seized for that that hi gehyrdon hine be pam cyrclicum they hear-PRET-PL he-ACC of the churchly

maðmum sprecan

(ÆCHom I,29 420.70)

treasures speak-INF

'Lo, then the soldiers seized him, for they heard him speak of the treasures of the church' 
Direct perception of St Lawrence's words in this homily is taken as evidence against him. He is seized by the soldiers of the prefect of Rome precisely because they have heard him mention the treasures of the church in his prayer (ÆCHom I,29 420.68). ${ }^{5}$ Both here and in (3), the focus is on hearing itself rather than on reported information (cf. Whitt 2010: 140).

Table 1. Direct auditory perception: (ge)hieran+ACI constructions

\begin{tabular}{lr}
\hline secgan & 10 \\
sprecan & 7 \\
mapelian & 2 \\
reccan & 1 \\
hrutan & 1 \\
huntan & 1 \\
Total & 22 \\
\hline
\end{tabular}

Previous research has shown that ACIs with verbs of direct perception are a common feature in Old Germanic languages (Callaway 1913: 185-186; Scheler 1961: 92; Mitchell 1985: \$\$3741-3743). Accordingly, we find similar uses of hôrian and heyra with an ACI complement in the ninth-century OS (Heliand) and ON (the Eddic Old Lay of Guthrun, whose composition is dated to before 1000, but the surviving manuscript to 13 th century):

(5) quâðun that sie ina selbon seggian gihôrdin, [they] said that they he-ACC self-ACC say-INF hear-PRET-3PL

that he [mahti] teuuerpen thena uuîh godes that he [could] knock-down that shrine of-god

(Heliand lx.5073-5074)

'they said that they had heard himself say that he could knock down the shrine of god'

(6) pá heyrir bú

then hear-PRES-2sG thou

$\begin{array}{ll}\text { hrafna } & \text { gjalla, } \\ \text { ravens-ACC } & \text { cry-INF } \\ \text { örnu } & \text { gjalla } \\ \text { eagles-ACC } & \text { cry-INF }\end{array}$

5. To prevent the church property being seized by the prefect, St Lawrence distributed it among the poor and suffering of Rome, for which he was imprisoned and martyred.

(C) 2013. John Benjamins Publishing Company

All rights reserved 


$$
\begin{aligned}
& \text { eezli fegna, } \\
& \text { carrion happy } \\
& \text { varga pjóta } \\
& \text { wolves-AcC howl-INF } \\
& \text { of veri binum } \\
& \text { of husband thine } \\
& \text { 'then you (will) hear / the ravens cry, / the eagles cry / happy with carrion, / } \\
& \text { the wolves howl / about your husband' }
\end{aligned}
$$

Here again direct auditory perception helps to interpret facts and to verify rumours: the guilt of Christ is established by the law-interpreters who have heard him promise to destroy the old temple (5), while the death of Sigurd is revealed to Gudrun by the cries of wolves and birds of carrion at his corpse (6).

\subsection{2 (ge)hieran+Inf}

First-hand auditory perception can also be coded by an (ge)hieran+Inf construction. In these cases, context typically suggests habitual events or immediate past reference, as below:

(7) On pam halgan godspelle pe ge gehyrdon nu rodan us on that holy gospel that ye hear-PRET-PL now read-INF us

segð be Lazare

(ÆHom 6 1)

says of Lazar

'in the holy gospel that you have heard [me] read just now we are told about Lazar'

Example (7) reflects a common medieval situation when people would listen to books being read to them but could not read themselves. Thus, here we can envisage a preacher who has just finished reading the Gospel in Latin (which is suggested by the adverb $n u$ ) and is now going to explain and comment on its contents in English. A direct reference to the preacher is, however, omitted.

A similar use of hôrian taking an infinitive without the accusative NP is found in the OS Heliand (ninth century):

(8) Manag fagonoda

many rejoiced

uuerod aftar [them] uuîha: gihôrdun uuilspel mikil

people at [the] shrine hear-PRET-3PL good-news great

fon gode seggean

(Heliand vi.526-528)

about god say-INF

'many rejoiced among the people at the shrine/[as] they heard say great and welcome news about God' 
This example refers to prophetess Anna whose words about the birth of the Saviour have been quoted in the preceding verses (cf. Luke 2.36-38). Thus, the source of information is omitted but can be retrieved from previous context. ${ }^{6}$

\subsection{3 (ge)hieran+Inf $+P P$}

This structure can be seen as an extension of (ge)hieran+Inf, in which the source of information is indicated overtly by a prepositional phrase with fram 'from', of 'from', or purh 'through' followed by an animate human noun:

(9) Ond monige men pa ðe pas ping gehyrdon secgan and many men when they these things hear-PRET-PL say-INF from poem forsprecenan were, weron boernde from that abovementioned man were kindled in geleafan

in faith

'And in many people who had heard this man speak about these things faith was kindled'

Similarly in the early-thirteenth-century Yngvar's Saga:

(10) Glúmr hafði numit at föður sínum, en pórir hafði numit af Glum had taken from father his, and Thorir had taken from Klökku Sámssyni, en Klakka hafði heyrt segja ina Klakka Samsson, and Klakka had hear-PART2 say-INF among fyrri freendr sina older of-family his

(Yngvars saga víðförla xiv)

'Glum had got it from his father, and Thorir had got it from Klakka Samsson, and Klakka had heard it told by the elders in his family'

Because my data on this type is limited to 3 occurrences of (ge)hieran+secgan+PP in $\mathrm{OE}$, it is rather difficult to conclude whether it is equivalent to the ACI construction: does I heard say from him imply I heard him say, and thus is it a clear case of direct evidentiality? As in 3.1.2. the interpretation depends on the focus. If it is placed on the information and its source, Examples (9) and (10) qualify as hearsay evidence; if, on the other hand, the focus is on hearing, they are direct auditory evidence (mark the importance of multiple witnesses in (9) and possible contrast between hafði numit and hafði heyrt segja in (10)). ${ }^{7}$

6. An alternative interpretation is proposed in 3.5.

7. Whitt is inclined towards the former interpretation (2010:142, 156-158).

(C) 2013. John Benjamins Publishing Company

All rights reserved 


\subsubsection{Gothic data}

My searches in the Project Wulfila database revealed that Gothic cognate of (ge) hieran - (ga)hausjan - can take accusativus cum participio (ACP) as complement. There are five constructions of this type with participle 1 (John 7.32; Luke 18.36; Mark 12.28, 14.58; and Thessalonians II 3.11) and two constructions with participle 2 (Luke 4.23, 9.7) in the Gothic New Testament.

\section{hausidedun pan Fareisaieis po managein}

hear-PRET-3PL then Pharisees this-ACC multitude-ACC

birodjandein bi ina pata

(John 7.32)

murmur-PART1-ACC about him this

'then the Pharisees heard people murmuring such things about him'

Closer examination showed, however, that all seven occurrences of the ACP translated similar participial constructions of the Greek original. There are no attestations of (ga)hausjan+ACP in the original Gothic Skeireins, a commentary on the Gospel of St John, to ascertain whether this construction could be used in Gothic independently of a Greek source text. Further my analysis of ACPs as complements of perception verbs in $\mathrm{OE}$ suggests that these constructions are also mostly found in translations from Latin (Timofeeva 2010:139-141). It seems therefore that the Gothic data on ACPs should best be treated as ambiguous and not be included in the typology of auditory evidential constructions in the Old Germanic languages.

\subsection{Indirect perception}

Indirect evidence requires either inference, reasoning, interpretation of the perceived information or verbal report, hearsay, folklore (Chafe 1986:268; Willett 1988:57-58). Both types of indirect evidence first have to be acquired through some form of perception (typically, visual or auditory) in order to be interpreted or passed on as hearsay (cf. Whitt 2010:10-11).

Inferential evidence in modern and present-day English is typically coded by see with a finite clause as complement (Boulonnais 2010:18-22; Whitt 2010:40, 57-61):

(12) Leaphorn could see Dashee was hating this. He'd pushed his uniform cap back on his head. His face was flushed. His forehead was beaded with perspiration.

(T. Hillerman, 1998, quoted in Boulonnais 2010:19)

This use of see involves a semantic shift SEE $\rightarrow$ REALISE/UNDERSTAND and includes seeing some signs or symptoms and interpreting their meaning. In (12) Leaphorn observes the cap, flushed face and perspiration of Dashee and concludes that the 
latter is uncomfortable and hates the situation he is in. Similarly in OE, inferential evidence is coded by visual ( $g$ e)seon 'see' (see Timofeeva 2010:138-141). Because inference indicated by auditory ( $g e$ hieran is not attested in my data, I do not discuss this evidential meaning any further, but concentrate instead on hearsay. According to Whitt (2010:136), hear+finite complement clause with or without that-complementiser is the default encoding of hearsay evidence:

(13) I heare she is worthe a thousande pounde and more. (Helsinki Corpus: CEPLAY1A, Nicholas Udall, Roister Doister (1500-1570), p. L. 131, quoted in Whitt 2010: 137)

The event has not been heard directly - nor can being worth a thousand pound and more be virtually heard - but acquired from a second-hand unspecified source. Importantly for the purposes of the present study, Whitt remarks that hearsay "sometimes is explicitly marked as such, i.e. the speech-act verb say occurs right alongside the perception verb hear" (2010: 138):

(14) I heard say that your husband would now put you in your hood, and silke gowne, I pray you is it true? (Helsinki Corpus: CEFICT2B, Thomas Deloney, Jack of Newbury (1619), p. 70, quoted in Whitt)

The content of the proposition in the complement clause was reported by a nonspecified individual(s) and perceived through hearing. We are now going to see what precursors this encoding of hearsay evidentiality had in OE and its cognate languages.

\subsection{1 (ge)hieran+Inf + poet- / wh-clause}

There are three ways to indicate hearsay evidence in OE, in which (ge)hieran cooccurs with a verb of utterance. The first one is to use a finite form of (ge)hieran with an infinitive (typically of the verb secgan, see Table 2 ) and a finite complement clause introduced by pot $^{8}$ ( 24 occurrences):

$$
\text { ic gehyrde secgan poet pu wore gleaw poron }
$$

I hear-PRET-1SG say-INF that thou were skilful thereon 'I have heard say that you are skilful in that [in interpreting dreams]'

$\begin{array}{lllll}\text { Forðam we gehyrað } & \text { reden on ðam godspelle peet Crist } \\ \text { for-that we hear-PRES-PL read-INF on that gospel that Christ }\end{array}$

8. Cross-linguistically this is often the underlying etymological structure of morphological hearsay evidentials (Anderson 1986:285). 
cwoede poet he were weig and soðfasnes and lyf

(Solil 1 51.11) said-subj that he were way and truth and life

'For we hear it read in the Gospel that Christ said that he was the way and truth and life'

The speaker (pharaoh) in (15) indicates that his information derives from an unspecified source. Although it has been perceived through hearing, auditory perception here is the means by which this information has been acquired rather than direct evidence for it. Similarly in (16), the focus is on the report of what Christ said, rather than on the fact that the Gospel was read and listened to. The proposition in the complement clauses may or may not be true (mark also the subjunctive of $p u$ wore and Crist cwode).

Further, there are 9 occurrences of finite wh-complement clauses after (ge) hieran+secgan, see example (1) which I reproduce here for convenience:

(1) Hwot, we nu gehyrdon secgan hwylc hit is on helle to bionne

(HomS 4 222)

Table 2. Hearsay evidence: (ge)hieran+Inf+poet- / wh-clause

\begin{tabular}{lr}
\hline secgan & 30 \\
cypan & 1 \\
reedan & 1 \\
reccan & 1 \\
Total & 33 \\
\hline
\end{tabular}

These encodings of hearsay evidence are attested in other Old Germanic languages, compare examples with OHG hôrran and ON heyra below: ${ }^{9}$
Ik gihorta
dat seggen,
I hear-PRET-1SG that say-INF
dat sih urhettun anon muotin:
that each-other challengers alone met

(Hildebrandslied 1-3)

Hiltibrant enti Hadubrant untar heriun tuem

Hildebrand and Hadubrand between armies two

'I have heard it say / that warriors met each other alone / Hildebrand and

Hadubrand, between two armies'

9. See also example (317) in Whitt (2010:156).

(C) 2013. John Benjamins Publishing Company

All rights reserved 
In ON (again I quote one of the Eddic lays recorded in the 13th century) the complement clause can be introduced by hvé:

Heyrða ek segja
hear-PRET-1sG I say-INF
$i$ sögum fornum,
in sagas old
hvé mor of kom
how maiden came
til Mornalands

(Oddrúnarkviða 1.1-4)

to Morningland

'I have heard say / in old sagas / how a maiden came / to Morningland'

Because both tokens occur in the opening lines of the poems (cf. also examples 19, 24, 26, 29, and the conclusion of Yngvar's Saga in 10), this suggests a common Germanic strategy to mark hearsay when a poet was about to begin his narrative and wanted to evoke the authority of the oral tradition (cf. a similar observation on Germanic and non-Indo-European heroic poetry in Bowra 1952:40).

\subsection{2 (ge)hieran $+\operatorname{Inf}+P P$}

Another way to introduce indirect evidence is to use a combination of 'hear' and 'say' together with 'about' prepositional phrase (be, fram, of, ymbe). PPs in this construction do not introduce the source of information (as in 3.1.3), but rather the focus of the report transmitted via hearsay. Only secgan and sprecan are attested in these constructions (see Table 3).

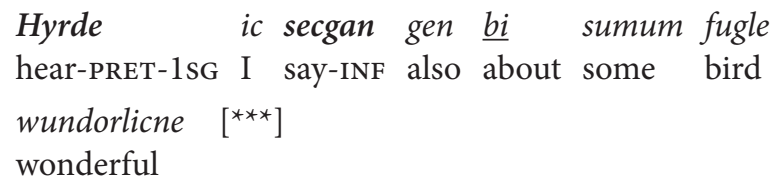

'In that place, people were accustomed to hearing reports about fish but none of them had ever seen a fish'

"Exotic" animals - partridge (19) and fish (20) - have never been observed in the communities implied in (19) and (20), but people know about them from folklore and other second-hand accounts.

(C) 2013. John Benjamins Publishing Company

All rights reserved 
Table 3. Hearsay evidence: (ge)hieran+Inf+'about'-PP

\begin{tabular}{lr}
\hline secgan & 24 \\
sprecan & 6 \\
Total & 30 \\
\hline
\end{tabular}

Hearsay markers with prepositional phrases are often found either within a relative clause - as in (21) - or in a superordinate clause that introduces a relative one - as in (22), where hearsay evidence is made even more tentative by the use of the pre-modal verb magan.

(21) Đa pohte ic poet poet wore seo helle pe ic oft on life then thought I that that were the hell that I often in life

embe secgan gehyrde

(ÆCHom II, 23 200.31)

about say-INF hear-PRET-1SG

'Then I thought that this was Hell about which I have often heard say'
Magon
we nu gehyran secgan be
suman halgan men may-PRES-PL we now hear-INF say-INF about some holy man
se woes on gastlice gesyhðe geloeded
(HomU 55 (Thorpe) 69)
that was in spiritual vision led
'Now we can hear say a story about a holy man who was instructed in a spiritual vision'

Again the emphasis is on the objects/persons - Hell and a holy man - that are introduced or described by the PPs, while the knowledge about them is clearly second-hand.

\subsection{3 (ge)hieran+secgan in swa-parentheticals}

Yet another way to encode hearsay is a parenthetical clause connected by means of swa 'so, as':

To pissum dagum purh haligne gast pis foesten o
to these days through holy ghost this fast and
pas gangdagas geset weron, swa we oft on bocum
the gang-days set were as we often in books
gehyrdon secgan
(Homs 33

hear-PRET-PL say-INF

'this fasting and the procession days have been observed until these days through the holy spirit, as we have often heard say in books'

We can only hypothesise a generic reference to some wise men of the books whose authority is evoked here to emphasise the importance of fasting and religious processions. Intensifying adverbs - such as oft 'often', gelome 'frequently',

(C) 2013. John Benjamins Publishing Company

All rights reserved 
and soplice 'indeed, truly' - can be used to emphasise the reliability of rumours or tradition.

(24) swa we soplice secgan hyrdon

(Beo 273)

as we truly say-INF hear-PRET-PL

'as we have truly heard say'

(25) swa we oft \& gelome secgan gehyrdon (HomS 24.1 (Scragg) 33) as we often and frequently say-INF hear-PRET-PL

'as we have often heard say'

A total of 12 swa-parentheticals (only with secgan) are attested in the DOEC.

There are several attestations of so-parentheticals in the early-thirteenthcentury manuscripts of the Song of the Nibelungs. The examples from the oldest manuscript B are lines 901, 3801, 7151, 7611, and 10561, all of them containing the following formula:

$\begin{array}{ll}\text { so wir horen } & \text { sagen } \\ \text { as we hear-PRES-PL } & \text { say-INF } \\ \text { 'as we hear say' } & \end{array}$

As we see, first person prevails in these constructions. Whitt observes that the use of hearsay markers with as-parentheticals in English (and with wie-parentheticals in German) signals a heightened degree of intersubjectivity "among parenthetical constructions ... There is a greater awareness of a larger speech community, and therefore an implicit acceptance of alternate possibilities of perception, evidence, and interpretations thereof" (2010: 150-151, at 151, cf. 164-165).

\subsubsection{Gothic data}

There is only one example of hausjan+ACI encoding hearsay evidence in the surviving Gothic texts.
unte gairnjands was
allaize izwara jah unwunands,
for longing he-was (after) of-all you and distressed
in pizei hausidedup ina siukan (Philippians 2.26)
in that hear-PRET-2PL he-ACC sick-INF/-ADJ-ACC
'for he longed after all of you and was distressed, because you had heard that he had been sick'

My gloss in (27) and the analysis of the compilers of the Wulfila Project indicate that the status of siukan is ambiguous: it can be interpreted both as an infinitive 
and as a weak masculine adjective in the accusative plural. Interestingly, hausidedup ina siukan translates a that-finite complement clause of the Greek source. Nevertheless, even if this example represents original Gothic usage, it is not possible to decide how it fits into the Old Germanic system of auditory evidentials, let alone to reconstruct whether anything like hausjan+ ${ }^{*}$ sagjan or hausjan+qipan had a place in it.

\subsection{Some conclusions}

This survey has shown that in terms of lexical means OE and other Old Germanic languages (with the exception of Gothic, for which we do not have enough data) seem to have similar ways of marking direct auditory perception and hearsay evidence. In fact the degree of overlap is high enough to suggest common origin of both hear+ACI and hear+Inf constructions in Proto-Germanic (or at least in West and North Germanic). More corpus research on individual languages and more comparative work on their later stages, therefore, would be very welcome as both will help to reveal diverging tendencies and to explain the differences of the present-day situation (see, e.g. Whitt 2010).

\subsection{Verbs of utterance and their syntactic context}

It may have become clear already that different verbs of utterance favour different types of syntactic context. In this section, I provide a brief survey of the structures in which verbs of utterance occur or which they take as complements. I begin with the less frequent and proceed to secgan.

\subsection{1 cwepan}

Both examples of cwepan have a to-PP complement occurring in a (ge)hieran+Inf construction. One of them is followed by direct speech:

(28) Me weran mine tearas for hlafas, agherge on doeg ge on to-me were my tears for bread, both on day and on niht; ponne ic gehyrde $\langle$ to $\rangle\langle m e\rangle$ cwepan, Hwor is pin night; then I hear-PRET-1sG to me say-INF, where is thy God, pe pu to hopast? (PPs (prose) 41.3) God, that thou hope-to 'I had my tears for bread night and day; and then I heard it spoken to me, Where is your God in whom you put hope'

No other verb in my data takes a to-PP. Both occurrences of (ge)hieran+cwepan imply direct auditory perception. 


\subsection{2 cypan}

On one occasion cypan takes poet-clause as complement:

(29) Hwot, we poet hyrdon purh halige bec

what, we that hear-PRET-PL through holy books

tacnum cyðan, poet twegen mid him

tokens tell-INF, that two with him

geprowedon, ond he woes pridda sylf

suffered, and he was third self

on rode treo

(El 852)

on rood tree

'Lo, we heard it told through symbols in the holy Gospels that two men suffered with him, and he himself was the third on the rood'

The source of information is introduced by purh-PP. Mark also that here (ge)hierancypan occurs again in the opening lines of the narrative, when St Helena is going to give a brief account of the crucifixion story to wise Jewish men in Jerusalem. The second instance of cypan is found in an extended phrase where (ge)hieran takes four infinitives as complements, while each infinitive takes an NP as direct complement in turn.
ponne we gehyron
Godes bec us beforan reccean
when we hear-PRES-SUBJ-1PL God's books us before explain-INF
\& reedan, \& godspell secggean, \& his wuldorprymmas
and read-INF, and gospel say-INF, and his heavenly-glories
mannum cypan
(HomU 20 (BlHom 10) 73)
to-men tell-INF
'when we would hear God's books explained and read before us, and gospel said, and his heavenly glories made known to people'

\subsection{3 mapelian}

The two instances of mapelian occur within ACI constructions (see Table 1), indicating direct auditory perception:

$$
\begin{aligned}
& \text { ponne ic sigedrihten, } \\
& \text { then I victory-lord }
\end{aligned}
$$

mihtigne god, moðlan gehyrde

mighty god speak-INF hear-PRET-1SG

strangre stemne, and me her stondan het

strange voice-ACC and me here stand ordered

(GenA,B 523)

'then, o Lord of victory, mighty God, I heard a strange voice speak, which ordered me to stand here' 


\subsection{4 nemnan}

Among the seven instances of (ge)hieran-nemnan, the following pattern emerges: nemnan occurs in a relative clause (4 instances) or a temporal clause (3 instances) and takes a direct object:

(32) Swelce pone meran morgensteorran, just-as that greater morning-star pe we oðre naman afensteorra that we other name evening-star

nemnan herað, $\quad \partial u$ genedest pone name-INF hear-PRES-1PL thou force that-one poet he pore sunnan sid bewitige that he that sun's journey observe (Met 4.13) 'Just as You force this greater morning-star [moon], which we also hear named by another name - evening-star, to observe the journey of the sun'

(33) ponne pu gehyrst nemnan pone foeder. ponne when thou hear-PRES-2sG name-INF that father, then understenst $p u$ Jaet he hoef sunu (ÆCHom I, 20 339.128) understandest thou that he has son 'when you hear Father mentioned, then you understand that he has a Son'

In 5 instances, direct objects are proper names as in (32). Only one example with nemnan in my data is an ACI construction (Beo 2023).

\subsection{5 reccan}

Reccan is typically used in combination with another infinitive: $\operatorname{secgan}$ ( 3 instances) and reedan ( 2 instances, see example (30)). It thus produces a somewhat tautological effect, which is, however, characteristic of many OE texts (see Koskenniemi 1968). Reccan is used once within an ACI construction (LS 13 (Machutus) 17r.17) and once to introduce a pret-clause (Bo 35.98.25).

\subsection{6 sprecan}

Like mapelian, sprecan has a tendency to be used in ACI constructions (see Table 1), as in example (2), which I reproduce here for convenience:

(2) Of poere tide, pe ic arest mid pe on pisum westene eardode, ic pe gehyrde sprecan on afenne and on arenmergen, ic nat mid hwoene

(LS 10.1 (Guth) 20.73)

This probably has to do with the fact that both verbs are semantically verbs of 'speaking' rather than 'saying/quoting' and are thus better suited to participate in direct auditory perception rather than hearsay (I return to this distinction shortly). Cf. also example (4). 


\subsection{7 roedan}

As has been observed in Section 3.1.2 (example (7)), (ge)hieran-rcedan reflects a situation specific to predominantly illiterate communities. ${ }^{10}$ The recurrence of this combination in the sources (particularly in homilies) points to the importance of reading aloud as part of religious life and instruction.

(7) On pam halgan godspelle pe ge gehyrdon nu rodan us segð be Lazare

(ÆHom 6 1)

The agent who does the actual reading can generally be reconstructed as 'priest' or 'preacher'. The distinction between those people in the audience who could read themselves and those who could not is made explicit in 6 instances out of 23:

$$
\begin{aligned}
& \text { ponne we bec reedað oððe radan gehyrad, } \\
& \text { when we books read-PREs-1PL or read-INF hear-PRES-1PL, } \\
& \text { ponne sprecð God to us purh pa } \\
& \text { then speaks God to us through those } \\
& \text { gastlican reedincge } \\
& \text { spiritual readings } \\
& \text { 'when we are reading the [holy] books or hear them read for us, God speaks } \\
& \text { to us through those spiritual readings' }
\end{aligned}
$$

Reedan typically (20 occurrences out of 23 ) takes an accusative NP as complement, which means either 'scripture,' 'gospel' or 'book' (normally synonymous to the former two) or then 'story, account' (referring to the Bible or lives of saints). Alternatively ( 3 occurrences) information source can be marked by an of- or on-PP (as in (7)).

\subsection{8 secgan}

Examples with secgan amount to some 64 per cent of my data and naturally present a greater variety of patterns, most of which, however, have featured in the above sections: ACIs in 3.1.1, pret- and wh-clauses in 3.2.1, PPs in 3.2.2, and swa-parentheticals in 3.2.3. Many other examples are combinations of the above patterns. I would like, however, to concentrate here on patterns that differ from those already discussed.

On four occasions (ge)hieran-secgan is used in an abbreviated negative clause without any complement or PP:

10. On the notions of mediated literacy and vocality (Vokalität) which describe such communities and the role of educated elites in them, see Schaefer (1992). I am grateful to Dr. Annina Seiler Rübekeil for this reference. 
(35) Sippan Romane poet gesawan poet him mon swelcne wrenc to then Romans that saw that them one such trick to dyde swelcne hie or $\underline{\text { ne gesawon ne secgan }}$ did such they before not saw nor say-INF

ne hirdon

not hear-PRET-PL

'Then the Romans realized that one has played such a trick at them, as they had never seen or heard told of before'

Negation eliminates all possible evidence here: such a thing was never witnessed visually and never heard of in a story, thus there is neither direct perception nor hearsay evidence for it.

Yet another pattern emerges in late $\mathrm{OE}$ :

Pa pe cyng Willelm geherde pet secgen, pa wearð
when the king William hear-PRET-3sG that say-INF then became
he swiðe wrað
he very angry
'when king William heard/learnt this, he got veryangry'
(ChronE 1066.35)
when hear-PRET-3sG Egelric bishop that say-INF then
amansumede he ealle pa men pa poet yfel doede
excommunicated he all those men who that evil deed

hoefden don

(ChronE 1070)

had done

'when bishop Ægelric heard/learnt this, he excommunicated all the men who had done this wicked deed'

In both instances, pet refers anaphorically to some piece of news reported via hearsay in the previous context. This use in my data is mostly limited to the late annals of the Anglo-Saxon Chronicle (6 occurrences altogether). According to my very preliminary research into ME infinitival phrases with similar structure, it gradually becomes more frequent; however, more corpus work and statistical checking would have to be done on this point. If my observations are correct, they will also have some bearing for the following hypothesis.

The fact that anaphoric patterns become slightly more frequent towards and during ME probably signals that semantic change is underway. What these new patterns do is state that someone got informed about a certain fact. Although the implication still is that the information was received through an auditory medium, hear-say no longer introduces a report but rather follows it. This change may point to a semantic development that involves a shift from 'hear-say' to 'learn/get 
informed.' This shift is also observable in more frequent (ge)hieran+Inf patterns. The following late OE example of a synonymous pair 'heard-say' - 'learnt' may point to the same conclusion about the semantic change:

(38) Mid by he gehyrde secgan and he leornode be when he hear-PRET-1SG say-INF and he learnt about pam ancerum (LS 10.1 (Guth) 2.106) that hermit

'When he found out and learnt about the hermit'

Further the word order of hear and say constituents becomes increasingly more bound, which also suggests that the two verbs may have been construed as one semantic unit, as below:

We iherden sacgen purh sumne wisne mon poet
we hear-PRET-PL say-INF through some wise men that
moyses... becom he to pare stowe pe inemnoed is
Moses... came he to that place which named is
quinquaginta finicas ... $\quad$ (LS 5 (InventCrossNap) 3) fifty palm-trees

'We have learnt from wise men that Moses came to a place called "fifty palm-trees"11 [Helim]'

(40) And eallswa se cynincg Carolus of Francene rice and also the king Charles of Franks' kingdom geherde secgan of his micclan godnesse (LS9 (Giles) 400) hear-PRET-3SG say-INF of his great virtue 'And also king Charles of France heard it told about his great virtue'

It has been observed cross-linguistically that the complement verb can be raised into the main clause and the two predications merged together to share one set of grammatical relations and one phonological outline. Thus the two verbs colexicalise (Noonan 1985:73-76; Givón 2001: ii, 59-63; Song 2001:278). I suggest that this process begins in $\mathrm{OE}$ and extends into the ME period. Univerbated heardsay spellings appear from ME2 onwards, so that conceptual and syntactic proximity, already observable in $\mathrm{OE}$, results in lexical and semantic unity and the emergence of a new lexical item. Because the OED dates the first attestation of the noun hear-saying to 1340 , I assume that the ultimate co-lexicalisation of the

11. Some mistake: Example 15.27 and Num 33.9 talk about seventy palm-trees.

(C) 2013. John Benjamins Publishing Company

All rights reserved 
verb hearsay should have taken place between 1250 and 1340 (but again more work is needed to verify this). Interestingly enough there is comparative evidence to support this scenario: in Middle High German the noun horsagen is attested from 1362 onwards (Mittelhochdeutsches Handwörterbuch, s.v. hoersagen). ${ }^{12}$ Thus, the development of German Hören-sagen might also have started with two verbs, which co-lexicalised into one and were later on converted into a noun.

To sum up, this survey has revealed that direct auditory perception in $\mathrm{OE}$ can be coded most unambiguously by the (ge)hieran+ACI construction. Statistically the verbs of 'speaking' - sprecan and mapelian - are used more frequently in ACIs than other verbs. The evidential meaning of the (ge)hieran+Inf construction (and its extensions) is predominantly hearsay evidence, although in 39 per cent of the occurrences of (ge)hieran+Inf, the agent of the infinitive can either be retrieved from previous context or reconstructed from our background knowledge of medieval routine practices (such as the reading practices discussed in 3.4.7) or overtly introduced by a PP (3.1.3). In these cases it is possible to interpret (ge)hieran+Inf as constructions that encode direct perception (but see Section 3.5 below). In terms of text types, two observations can be made: hearsay evidential constructions are prominent in poetry where they are used to refer to the oral tradition (which is in line with Aikhenvald's observations (2004:310-315)), and in sermons and homilies where they are used to evoke the authority of the Bible, the Church Fathers, etc. Secgan is the most frequent verb, it is used in all types of constructions discussed above, indicating both direct perception and hearsay evidence. Its frequency seems to have contributed to the semantic shift 'hear-say' $\rightarrow$ 'get informed, learn' and the ultimate univerbation of hearsay in the Middle English period. Comparative data from other Old Germanic languages suggests that these evidential constructions and some of their diachronic developments might not be unique to Old English.

\subsection{Origin}

It has been observed that the division of infinitival complements into ACIs and infinitives without the accusative subjects seems to coincide with the semantic division of verbs into 'speaking' and 'saying/quoting' respectively. I would like to argue that these divisions correspond to deeper structural differences than may at first sight seem. The emergence of such structures as OE He heard say is normally

12. Cf. also DWB Online, s.vv. Hörensagen, Hörsage, and Hörsagen. Swedish also has hörsägen 'hearsay, rumours', which is a clear case of loan translation from German, dated to as late as 1865 (Ordbok över svenska språket, s.v. höra).

(C) 2013. John Benjamins Publishing Company

All rights reserved 
seen as an ellipsis of He heard people say. ${ }^{13}$ However, I do not see the existence He heard people say as a necessary precursor of He heard say.

It is well known that Indo-European infinitives go back to verbal nouns, and Germanic infinitives (those that give rise to the so-called 'uninflected form') go back to verbal nouns in the accusative -onom (e.g. Beekes 1995:251). Reconstructions of the origin and evolution of ACI constructions in Indo-European also suggest that infinitives were initially more nouny and only later developed tense, voice and mood characteristics (Coleman 1985:308-311, 327, 332). Moreover, the accusative in ACIs is the result of reanalysis of some other case - genitive, accusative, dative, or even locative (see Woodcock 1959:17; Coleman 1985:310-311, and a summary in Timofeeva 2010:77-78).

Further, Ross (1973/2004) advocates the existence of a linear squish between verbs and nouns that allows for a "quasi-continuous hierarchy" between the two categories, whose boundaries become increasingly blurred towards the centre of the squish. Ross sees the nouniness squish as.

(40) that $>$ for to $>\mathrm{Q}>$ Acc Ing $>$ Poss Ing $>$ Action nominal $>$ Derived nominal $>$ Noun

These types of complements can be exemplified as follows:

(41) a. that = that-clauses (that Max gave the letters to Frieda)

b. for to $=$ for NP to V X (for Max to have given the letters to Frieda)

c. $\mathrm{Q}=$ embedded questions (how willingly Max gave the letters to Frieda)

d. Acc Ing $=[\mathrm{NP}+\mathrm{Acc}] \mathrm{V}+$ ing X (Max giving the letters to Frieda)

e. $\quad$ Poss Ing $=$ NP's + ing X (Max's giving letters to Frieda)

f. Action Nominal ( $\{$ Max's/the $\}$ giving of the letters to Frieda)

g. Derived Nominal ( $\{$ Max's/the $\}$ gift of the letters to Frieda)

h. Noun (spatula)

(Ross 1973/2004:1)

Ross's quasi-hierarchy suggests that "some squish of nouniness," some "squishoid" system, rather than the clear-cut categories of verb and noun, is part of every speaker's language competence (1973/2004:389-391). This explains the diversity of nouny and verby forms synchronically. I believe, however, that nouniness squish can also explain why Indo-European verbal nouns could be reanalysed as infinitives in the first place, and, thus, account for the diachronic developments. If there is indeed a noun-verb continuum, we might expect the fuzzy verbals and nominals in its middle portion to evolve towards more verby or more nouny categories. Suppose we see Ross's (g) through (d) chronologically:

13. Cf. OED, s.v. hear 3b: "Hence, by ellipsis of such objects as people, persons, some one, before the infinitives say, speak, talk, tell, the phrases to hear say, hear tell, etc. [emerge]."

(C) 2013. John Benjamins Publishing Company

All rights reserved 
(42)

Derived Nominal $>$ Action Nominal $>$ Poss Ing $>$ Acc Ing

If we apply this scenario to the category of 'speaking' noun-verb continuum, we could reconstruct the development of hear+ACI as:

(43) I heard his speech > I heard his speaking $>$ I heard his speak > I heard him speak

in which nouns gradually acquire verby features and develop into infinitives, while the possessive is reanalysed as accusative. This construction from the outset focuses on sounds (including sounds of speech) and source/agent of the sounds, hence direct perception evidentials are more likely to develop from this pattern.

The stages in the development of constructions with verbs of 'saying/quoting' can be reconstructed as follows:

(44) I heard $\{$ his/the $\}$ story $^{14}>$ I heard $\{$ his/the $\}$ saying $>$

a. > I heard his say $>$ I heard him say

b. > I heard (the) say

For this type, sounds (media) are much less relevant than stories (results), hence hear+Inf constructions coding hearsay evidence are probably more likely to develop here (44b). However, this does not exclude the possibility of a parallel development of ACIs with 'say' (44a) by analogy with ACIs with 'speak' or independently of them.

One further piece of evidence to support the development $I$ heard the story $>I$ heard say is that (ge)hieran+Inf but not (ge)hieran+ACI allows for a PP extension. The emergence of constructions with PPs indicating the source of information can be seen as:

(45) I heard this story from my dad $>\ldots>$ I heard say from my dad

Thus the answer to my own query in 3.1.3 is that I heard say from him and I heard him say are not equivalent, neither structurally nor semantically. The following reconstruction can be proposed for $(g e) h i e r a n+I n f+P P$ indicating the focus of the report:

(46) I heard a story about a bird $>\ldots>$ I heard say about a bird

All in all, I suggest that the ellipsis of the accusative in the ACI construction cannot account for the emergence of (ge)hieran+Inf, which is different from the ACI both in structure and in evidential semantics. Moreover, chronologically, and my corpus evidence with the preponderance of (ge)hieran+Inf over (ge)hieran+ACI occurrences seems to support this, $(\mathrm{ge})$ hieran+Inf was probably the first to emerge,

14. Etymologically saga would probably be more appropriate here.

(C) 2013. John Benjamins Publishing Company

All rights reserved 
as cross-linguistically hearsay evidence is marked more often than direct auditory perception (Cinque 1999:85; Aikhenvald 2004:23, 31-34, 75-78). As the infinitives became more verby, however, hear+Inf is likely to have been reanalysed as ACI with ellipsis, or even as something less grammatical than the ACI, and eventually became obsolescent when new lexical means, e.g. hearsay adverbs reportedly, allegedly, etc. came into being. I believe that in the case of hear+say construction, univerbation of hearsay in ME2 and the emergence of the noun hearsay in early ME3 can be taken as the terminus post quem this structure became less analysable. These stages are, however, open to debate and further research.

\section{Acknowledgements}

The early stages of this study were supported by the Academy of Finland Centre of Excellence funding for the Research Unit for Variation, Contacts and Change in English at the Department of Modern Languages, University of Helsinki, to which I am most grateful. My special thanks are due to Richard J. Whitt, who sent me his excellent book, Evidentiality and Perception Verbs in English and German, and to Dominique Boulonnais, who read and commented on the draft of the article and kindly helped me with some references. I would also like to thank the audience, participants, and organisers of the Verbal Categories workshop at the 16th International Conference of English Historical Linguistics in Pécs in 2010, and the anonymous reviewers of this volume for their helpful feedback.

\section{References}

\section{Electronic sources}

CME = The Corpus of Middle English Prose and Verse. 2006. University of Michigan. 〈http:// quod.lib.umich.edu/c/cme/>

DOEC = Dictionary of Old English Web Corpus. 2009. Ed. by Antonette diPaolo Healey, with John Price Wilkin \& Xin Xiang. University of Toronto. 〈http://tapor.library.utoronto.ca/ doecorpus/>

DWB = Das Deutsche Wörterbuch von Jacob und Wilhelm Grimm auf CD-ROM und im Internet. 1998-2011. University of Trier. 〈http://woerterbuchnetz.de/DWB/〉

Heimskringla Project. Ongoing. Ed. by Jon Julius Sandal \& Carsten Lyngdrup Madsen. 〈www. heimskringla.no>

OED = The Oxford English Dictionary Online. 2010. OUP. 〈http://www.oed.com〉

Mittelhochdeutsches Handwörterbuch. 1998-2011. Ed. by Matthias Lexer. University of Trier. 〈http://woerterbuchnetz.de/Lexer/〉

Project Wulfila. 2004. University of Antwerp. 〈http://www.wulfila.be/〉 
TITUS = Thesaurus Indogermanischer Text- und Sprachmaterialien. 2008. Ed. by Jost Gippert, Javier Martínez \& Agnes Korn. 〈http://titus.fkidg1.uni-frankfurt.de〉

YCOE $=$ York-Toronto-Helsinki Parsed Corpus of Old English Prose. 2003. Ed. by Ann Taylor, Anthony Warner, Susan Pintzuk \& Frank Beths. University of York. 〈http://www-users. york.ac.uk/ lang22/YcoeHome1.htm〉

\section{Secondary sources}

Aikhenvald, Alexandra Y. 2004. Evidentiality. Oxford: OUP.

Anderson, Lloyd B. 1986. Evidentials, paths of change, and mental maps: Typologically regular asymmetries. In Chafe \& Nichols (eds), 273-312.

Beekes, Robert S.P. 1995. Comparative Indo-European Linguistics: An Introduction. Amsterdam: John Benjamins.

Boulonnais, Dominique. 2010. Verbes de perception et modes de complémentation verbale. In Perception et structures linguistiques: Huit études sur l'anglais [Rivages linguistiques], JeanCharles Khalifa \& Philip Miller (eds), 15-89. Rennes: Presses Universitaires de Rennes.

Bowra, Cecil Maurice. 1952. Heroic Poetry. London: Macmillan.

Callaway, Morgan Jr. 1913. The Infinitive in Anglo-Saxon. Washington DC: Carnegie Institution.

Chafe, Wallace. 1986. Evidentiality in English conversation and academic writing. In Chafe \& Nichols (eds), 261-312.

Chafe, Wallace \& Nichols, Johanna (eds). 1986. Evidentiality: The Linguistic Coding of Epistemology [Advances in Discourse Processes 20]. Norwood NJ: Ablex.

Cinque, Guglielmo. 1999. Adverbs and Functional Heads: A Cross-linguistic Perspective [Oxford Studies in Comparative Syntax]. Oxford: OUP.

Coleman, Robert. 1985. The Indo-European origins and Latin development of the accusative with infinitive construction. In Syntaxe et Latin, Actes du IIème Congrès International de Linguistique Latine, Aix-en-Provence, 28-31 mars 1983, Christian Touratier (ed.), 307-342. Aix-en-Provence: Université de Provence.

Diewald, Gabriele \& Smirnova, Elena (eds). 2010a. Linguistic Realization of Evidentiality in European Languages [Empirical Approaches to Language Typology 49]. Berlin: De Gruyter Mouton.

Diewald, Gabriele \& Smirnova, Elena. 2010b. Introduction. Evidentiality in European languages: The lexical-grammatical distinction. In Diewald \& Smirnova (eds), 1-14.

Givón, Talmy. 2001. Syntax: An Introduction, 2 Vols. Amsterdam: John Benjamins.

Kilpiö, Matti \& Timofeeva, Olga. 2011. Semantic polyfunctionality and grammaticalization of the OE subordinator be poem pe: A corpus-based study. In Typology of Adverbial Connectives [Studies in Variation, Contacts and Change in English 8], Anneli Meurman-Solin \& Ursula Lenker (eds). VARIENG ePublications. 〈http://www.helsinki.fi/varieng/journal/ volumes/08/kilpio_timofeeva/>

Koskenniemi, Inna. 1968. Repetitive Words Pairs in Old and Early Middle English Prose. Turku: Turun yliopiston julkaisuja, B, 107.

Mitchell, Bruce. 1985. Old English Syntax, 2 vols. Oxford: Clarendon Press.

Mittelhochdeutsches Handwörterbuch. 1872. 1 Band. Ed. by Matthias Lexer. Leipzig: Verlag von S. Hirzel.

Noonan, Michael. 1985. Complementation. In Language Typology and Syntactic Description, Vol. 2: Complex Constructions, Timothy Shopen (ed.), 42-140. Cambridge: CUP. 
Ordbok över svenska språket utgiven av Svenska Akademien. 1933. 12 Bandet. Lund: A.-B. Ph. Lindstedts Univ. - Bokhandel.

Plungian, Vladimir. 2010. Types of verbal evidentiality marking: An overview. In Diewald \& Smirnova (eds), 15-58.

Ross, John Robert. 1973/2004. Nouniness. In Three Dimensions of Linguistic Research, Osamu Fujimura (ed.), 137-257. Tokyo: TEC. Reprinted in Fuzzy Grammar: A Reader, Bas Aarts, David Denison, Evelien Keizer \& Gergana Popova (eds) 351-422. Oxford: OUP.

Schaefer, Ursula. 1992. Vokalität: Altenglische Dichtung zwischen Mündlichkeit und Schriftlichkeit [ScriptOralia 39]. Tübingen: Gunter Narr.

Scheler, Manfred. 1961. Altenglische Lehnsyntax: Die syntaktischen Latinismen im Altenglischen. Ph.D. dissertation. Berlin: Free University.

Song, Jae Jung. 2001. Linguistic Typology: Morphology and Syntax. Harlow: Longman.

Timofeeva, Olga. 2010. Non-finite Constructions in Old English, with Special Reference to Syntactic Borrowing from Latin. Ph.D. dissertation, Mémoires de la Société Néophilologique de Helsinki LXXX, Helsinki: Société Néophilologique.

Whitt, Richard J. 2010. Evidentiality and Perception Verbs in English and German [German Linguistic and Cultural Studies 26]. Oxford: Peter Lang.

Wiemer, Björn. 2010. Hearsay in European languages: Toward an integrative account of grammatical and lexical marking. In Diewald \& Smirnova (eds), 59-129.

Willett, Thomas. 1988. A cross-linguistic survey of the grammaticalization of evidentiality. Studies in Language 12(1): 51-97.

Woodcock, Eric Charles. 1959. A New Latin Syntax. London: Methuen \& Co. 